\title{
Synthesis of Cu-Poor Copper-Indium-Gallium-Diselenide Nanoparticles by Solvothermal Route for Solar Cell Applications
}

\author{
Chung Ping Liu,, ${ }^{1,2}$ Ming Wei Chang, ${ }^{1}$ Chuan Lung Chuang, ${ }^{1}$ and Nien Po Chen ${ }^{1}$ \\ ${ }^{1}$ Department of Photonics Engineering, Yuan Ze University, 135 Yuan Tung Road, Chungli 320, Taiwan \\ ${ }^{2}$ Department of Physics, Fu Jen Catholic University, 510 Zhongzheng Road, Xinzhuang District, New Taipei 242, Taiwan \\ Correspondence should be addressed to Chung Ping Liu; eecpliu@saturn.yzu.edu.tw
}

Received 18 December 2013; Revised 24 January 2014; Accepted 29 January 2014; Published 2 March 2014

Academic Editor: Raghu N. Bhattacharya

Copyright (c) 2014 Chung Ping Liu et al. This is an open access article distributed under the Creative Commons Attribution License, which permits unrestricted use, distribution, and reproduction in any medium, provided the original work is properly cited.

\begin{abstract}
Copper-indium-gallium-diselenide (CIGS) thin films were fabricated using precursor nanoparticle ink and sintering technology. The precursor was a Cu-poor quaternary compound with constituent ratios of $\mathrm{Cu} /(\mathrm{In}+\mathrm{Ga})=0.603, \mathrm{Ga} /(\mathrm{In}+\mathrm{Ga})=0.674$, and $\mathrm{Se} /(\mathrm{Cu}+\mathrm{In}+\mathrm{Ga})=1.036$. Cu-poor CIGS nanoparticles of chalcopyrite for solar cells were successfully synthesized using a relatively simple and convenient elemental solvothermal route. After a fixed reaction time of $36 \mathrm{~h}$ at $180^{\circ} \mathrm{C}$, CIGS nanocrystals with diameters in the range of 20-70 nm were observed. The nanoparticle ink was fabricated by mixing CIGS nanoparticles, a solvent, and an organic polymer. Analytical results reveal that the $\mathrm{Cu}$-poor CIGS absorption layer prepared from a nanoparticle-ink polymer by sintering has a chalcopyrite structure and a favorable composition. For this kind of sample, its mole ratio of $\mathrm{Cu}: \mathrm{In}: \mathrm{Ga}: \mathrm{Se}$ is equal to $0.617: 0.410: 0.510: 2.464$ and related ratios of $\mathrm{Ga} /(\mathrm{In}+\mathrm{Ga})$ and $\mathrm{Cu} /(\mathrm{In}+\mathrm{Ga})$ are 0.554 and 0.671 , respectively. Under the condition of standard air mass 1.5 global illumination, the conversion efficiency of the solar cell fabricated by this kind of sample is $4.05 \%$.
\end{abstract}

\section{Introduction}

CIGS-based solar cells have great potential for use in portable devices because of their high absorption coefficient, wide absorption spectrum, and high stability. Chalcopyrite compounds of CuInGaSe ${ }_{2}$ and related alloys are among the most promising materials for photovoltaic applications [1]. Recent studies have demonstrated efficiencies of thin-film CIGSbased solar cells as high as $20.3 \%$ [2].

Chalcopyrites are well known to form a stable phase at significant deviations from stoichiometry, ranging from $\mathrm{Cu}-$ poor $([\mathrm{Cu}] /[\mathrm{In}+\mathrm{Ga}]<1)[3-5]$ to $\mathrm{Cu}$-rich $([\mathrm{Cu}] /[\mathrm{In}+$ $\mathrm{Ga}$ ] > 1) [6]. Many authors had studied the formation of secondary phases over the surface of nonstoichiometric $\mathrm{Cu}\left(\mathrm{In}_{1-x} \mathrm{Ga}_{x}\right) \mathrm{Se}_{2}$ thin film and its effect on solar cell performance $[7,8]$. At In-rich phases, such as $\mathrm{Cu}\left(\operatorname{In}_{1-x} \mathrm{Ga}_{x}\right)_{2} \mathrm{Se}_{35}$, $\mathrm{Cu}\left(\mathrm{In}_{1-x} \mathrm{Ga}_{x}\right)_{3} \mathrm{Se}_{5}$, or $\mathrm{Cu}\left(\mathrm{In}_{1-x} \mathrm{Ga}_{x}\right)_{5} \mathrm{Se}_{8}, \mathrm{Cu}$-poor CIGS films are likely to be formed at the surface because of deficiencies of $\mathrm{Cu}$ and Se there. Of these phases, $\mathrm{Cu}\left(\mathrm{In}_{1-x} \mathrm{Ga}_{x}\right)_{3} \mathrm{Se}_{5}$, which are an ordered vacancy compound (OVC) or an ordered defect compound (ODC), are considered important to affect the performance of the highly efficient CIGSbased solar cells [8-10]. Compared with the stoichiometric $\mathrm{Cu}\left(\mathrm{In}_{1-x} \mathrm{Ga}_{x}\right) \mathrm{Se}_{2}$ film (so-called $\alpha$ phase), a $\mathrm{Cu}$ poor CIGS film can contain three compositionally different phases-the $\mathrm{Cu}$-poor $\alpha$ phase $\mathrm{Cu}\left(\mathrm{In}_{1-x} \mathrm{Ga}_{x}\right) \mathrm{Se}_{2}$, the $\beta$ phase $\mathrm{Cu}\left(\mathrm{In}_{1-x} \mathrm{Ga}_{x}\right)_{3} \mathrm{Se}_{5}$ or $\mathrm{Cu}\left(\mathrm{In}_{1-x} \mathrm{Ga}_{x}\right)_{2} \mathrm{Se}_{3,5}$, and the $\gamma$ phase $\mathrm{Cu}\left(\mathrm{In}_{1-x} \mathrm{Ga}_{x}\right)_{5} \mathrm{Se}_{8}$ [11]. The $\alpha, \beta$, and $\gamma$ phases exhibit chalcopyrite, ODC, and layered structures, respectively.

A set of low-cost methods with the realistic possibility of reducing direct manufacturing cost have been developed in the past five years. Recently, CIGS absorbing layers have been fabricated using nanoparticles [12-14] and other coating methods. Two nanoparticle-based methods are used to form a CIGS absorption layer. One is the preparation of a precursor film by synthesizing CIGS powder [12] and the other is a mechanochemical process (MCP) [13], such as a rotary ball milling (RBM) method that is implemented before nonvacuum coating [14]. In an MCP, the four elemental metal powders of $\mathrm{Cu}, \mathrm{In}, \mathrm{Ga}$, and Se are mixed and milled by planetary ball milling, yielding particles of size $1 \mu \mathrm{m}$ [13]. In the RBM, the precursor has quaternary compound 
composition ratios of $\mathrm{Cu} /(\mathrm{In}+\mathrm{Ga})=0.95, \mathrm{Ga} /(\mathrm{In}+\mathrm{Ga})=$ 0.39 , and $\mathrm{Se} /(\mathrm{Cu}+\mathrm{In}+\mathrm{Ga})=0.75$. After milling, the particles of the agglomerated CIGS powder have diameters of less than $100 \mathrm{~nm}$ [14]. Follow, thermal sintering can form a dense absorption layer on precursor films for use in solar cells [15]. All steps that are conducted in a nonvacuum environment are relatively simple and inexpensive, facilitating scaling-up [16] and control of the ratios of the metal concentrations. In 2011, Lee et al. [17] developed a nanoparticle-based method using a precursor solution for fabricating printable CIGS thin-film solar cells at low cost. They obtained an almost carbon-free CIGS film by applying a three-step heat treatment process: the first step is the elimination of carbon residues by annealing in air; the second step is the formation of CIGS alloys by sulfurization, and the third step is the growth of grains and the densification of CIGS films by selenization.

This work is going to develop another process for fabricating a Cu-poor CIGS absorption layer precursor using a quaternary compound with constituent ratios of $\mathrm{Cu} /(\mathrm{In}+\mathrm{Ga})$ $=0.603, \mathrm{Ga} /(\mathrm{In}+\mathrm{Ga})=0.674$, and $\mathrm{Se} /(\mathrm{Cu}+\mathrm{In}+\mathrm{Ga})=1.036$. $\mathrm{Cu}$-poor CIGS nanoparticles used for solar cells were successfully synthesized by using a relatively simple and convenient elemental solvothermal route. The nanoparticle ink could be fabricated by mixing CIGS nanoparticles, a solvent, and an organic polymer. The Cu-poor CIGS absorption layer that was prepared by sintering with a nanoparticle-ink polymer had a chalcopyrite structure. Its favorable composition was examined and analyzed by making various energy dispersive spectrometric (EDS) measurements; the morphologies of the samples were determined by scanning electron microscopy (SEM); their electrical properties were analyzed by making Hall effect measurements; their crystallographic structures were determined using X-ray diffraction (XRD). Solar cells that were produced using this sample were analyzed; their $I-V$ characteristics under illumination were obtained by simulation under standard test conditions of AM 1.5 G and $1000 \mathrm{~W} / \mathrm{m}^{2}$ at $25^{\circ} \mathrm{C}$.

\section{Experimental}

An Mo thin-film electrode layer was prepared by using the DC magnetron sputtering process [18]. In order to form an Mo layer with a thickness of $350 \mathrm{~nm}$, its deposition conditions were a temperature of $150^{\circ} \mathrm{C}$, a chamber working pressure of 3-4 mtorr, and a deposition rate of $20 \mathrm{~nm} / \mathrm{min}$.

The elemental solvothermal procedure that can be found in the literature [19] was used to produce the CIGS nanoparticles. Adding elemental gallium in the CIS synthesis reduces the reaction temperature required to obtain CIGS particles because gallium has a lower melting temperature than the other reactants. $\mathrm{Cu}$ powder $(99.99 \%, 5 \mathrm{~N}$ plus), In powder (99.95\%, Swiftek), $\mathrm{Ga}\left(\mathrm{NO}_{3}\right)_{3}$ (99.99\%, Spectrum), and Se powder $(99.95 \%, 5 \mathrm{~N}$ plus) were used as raw materials, whereas the solvent was ethylenediamine (99\%, Spectrum). Analytical grade reactants of $\mathrm{Cu}(1.04 \mathrm{~g}, 0.0164 \mathrm{~mol})$, In $(1.0 \mathrm{~g}$, $0.0087 \mathrm{~mol}), \mathrm{Ga}\left(\mathrm{NO}_{3}\right)_{3}(4.5 \mathrm{~g}, 0.0176 \mathrm{~mol})$, and $\mathrm{Se}(3.55 \mathrm{~g}$, $0.0499 \mathrm{~mol}$ ) powders were loaded into a $100 \mathrm{~mL}$ Teflon-lined autoclave, which was then no more than half-filled with anhydrous ethylenediamine. The precursor of the preparation of CIGS nanoparticles was fabricated by the following steps [20].

Step 1. When the reaction temperature exceeds the melting temperature of indium metal, the indium formed an $\mathrm{In}_{2} \mathrm{Se}_{3}$ phase and liquid droplets which could be attached to the solid phase.

$$
2 \mathrm{In}+6 \mathrm{Se}+3 \mathrm{Se}^{2-} \longrightarrow \mathrm{In}_{2} \mathrm{Se}_{3}+6 \mathrm{Se}^{-}
$$

Step 2. Gallium can also form a $\mathrm{Ga}_{2} \mathrm{Se}_{3}$ phase and liquid droplet as

$$
2 \mathrm{Ga}+6 \mathrm{Se}+3 \mathrm{Se}^{2-} \longrightarrow \mathrm{Ga}_{2} \mathrm{Se}_{3}+6 \mathrm{Se}^{-}
$$

Step 3. Then, $\mathrm{Cu}^{+}$and $\mathrm{Se}^{2-}$ ions from the solution are fed into liquid droplets (In and $\mathrm{Ga}$ ) and got (3) as

$$
\begin{gathered}
\mathrm{In}_{2} \mathrm{Se}_{3}+\mathrm{Ga}_{2} \mathrm{Se}_{3}+4\left[\mathrm{Cu}(\mathrm{en})_{2}\right]^{+}+2 \mathrm{Se}^{-2} \\
\longrightarrow 4\left(\mathrm{Cu}\left(\mathrm{In}_{1-x} \mathrm{Ga}_{x}\right)_{1.65} \mathrm{Se}_{2.35}\right)
\end{gathered}
$$

The sealed autoclave was maintained at a reaction temperature of $180^{\circ} \mathrm{C}$ for $36 \mathrm{~h}$ and then cooled to room temperature in the furnace. The synthesized powders were firstly washed with anhydrous ethanol to remove by-products, and then they were vacuum-dried at $80^{\circ} \mathrm{C}$ to obtain the required drying CIGS nanoparticles. Closely examining scanning electron microscope (SEM) photographs of the agglomerated CIGS powder revealed an average grain size of smaller than $70 \mathrm{~nm}$ (Figure 1). To obtain the information about chemical composition of nanoparticles, each product had been analyzed with EDS (Figure 2). The precursor utilized a quaternary compound with constituent ratios of $\mathrm{Cu} /(\mathrm{In}+\mathrm{Ga})=0.603$, $\mathrm{Ga} /(\mathrm{In}+\mathrm{Ga})=0.674$, and $\mathrm{Se} /(\mathrm{Cu}+\mathrm{In}+\mathrm{Ga})=1.036 . \mathrm{A}$ mixed precursor solution was prepared by dissolving the necessary amount of CIGS (5 g) in propanol $(20 \mathrm{~mL})$ and then adding triethylenetetramine $(1.0 \mathrm{~mL})$, polyvinylidene fluoride (PVDF, $1.0 \mathrm{~g}$ ), and dimethylformamide solution $(16 \mathrm{~mL})$. Under reduced pressure, the condensation of mixed solution at $50^{\circ} \mathrm{C}$ would yield a viscous paste with rheological properties that were appropriate for coating by means of a doctor's blade.

The CIGS nanoparticle ink was coated onto the Mo/glass substrate using a doctor's blade. The solvent was then removed by placing the sample into an oven and increasing the temperature from $25^{\circ} \mathrm{C}$ to $120^{\circ} \mathrm{C}$ with a rate of $20^{\circ} \mathrm{C} / \mathrm{min}$, which was maintained for $5 \mathrm{~min}$. After the oven was turned off and the sample cooled to less than $25^{\circ} \mathrm{C}$, the required dry precursor films could be obtained. Thus, the performance of the precursor films could be evaluated by SEM. A crosssectional SEM photograph of a CIGS precursor sample (Figure 3) reveals that the sample has a thickness of $\sim 2 \mu \mathrm{m}$.

The prepared precursor sample was heated in a rapid thermal annealing (RTA) furnace to yield a highly crystalline state of CIGS. Before sintering, the sample was firstly placed in a graphite box and the graphite plate was completely 


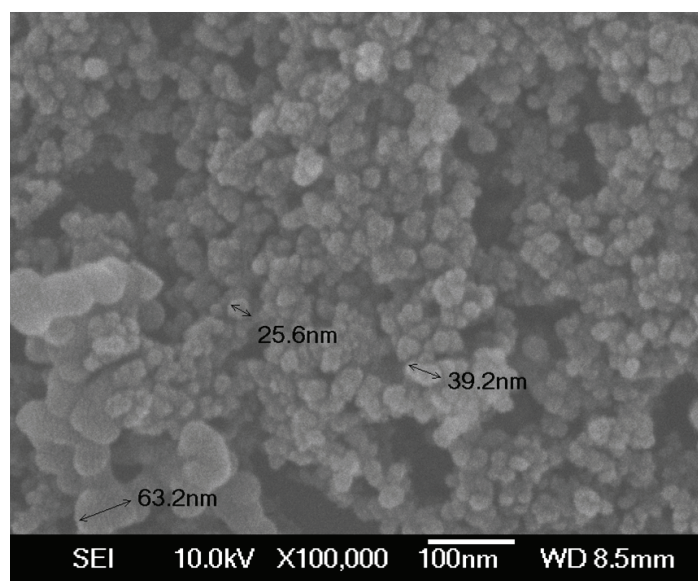

FIGURE 1: SEM photographs of agglomerated CIGS powder, revealing average grain size of smaller than $70 \mathrm{~nm}$.

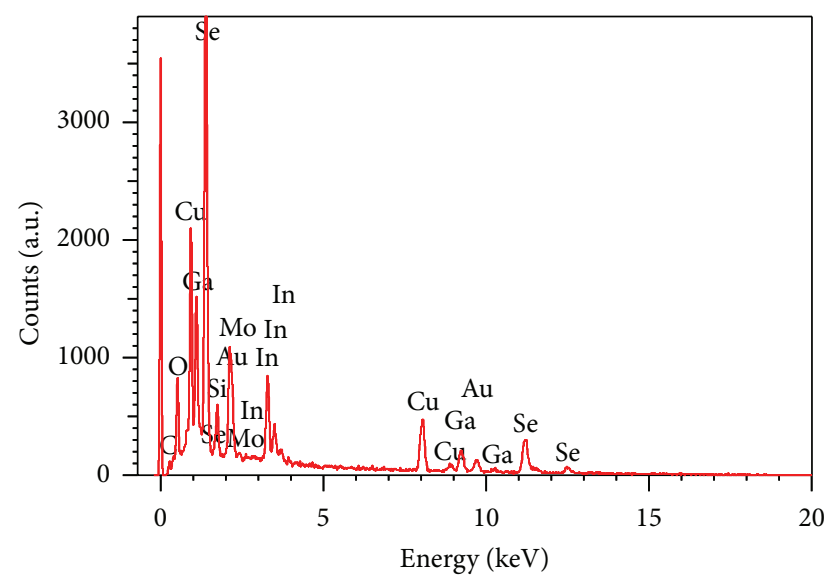

FIGURE 2: EDS photograph of CIGS sample before sintering.

covered with selenium powders of $2.5 \mathrm{~g}$, and then the sample was placed into a tube furnace. Successively, the nitrogen gas with a flow rate of $200 \mathrm{sccm}$ was introduced into the quartz tube, coming in from one end and going out from the other end. Both processes of sintering and selenization were performed at $520^{\circ} \mathrm{C}$ for $30 \mathrm{~min}$, and then the sample was cooled to less than $50^{\circ} \mathrm{C}$. Thus, the solar cell devices could be fabricated according to conventional configuration of ITO/ZnO/CdS/CIGS/Mo/glass.

\section{Results and Discussion}

3.1. Composition and Electrical Properties of CIGS Film. The stoichiometric compositions of sintered CIGS samples could be analyzed by using energy dispersive spectrometric (EDS) data. The EDS spectrum of the CIGS absorption layer for use in solar cells, as shown in Figure 4, indicated that the atomic proportions were $\mathrm{Cu}=15.42 \%, \mathrm{In}=10.24 \%, \mathrm{Ga}=12.74 \%$, and $\mathrm{Se}=61.60 \%$, respectively. Based on these data, the

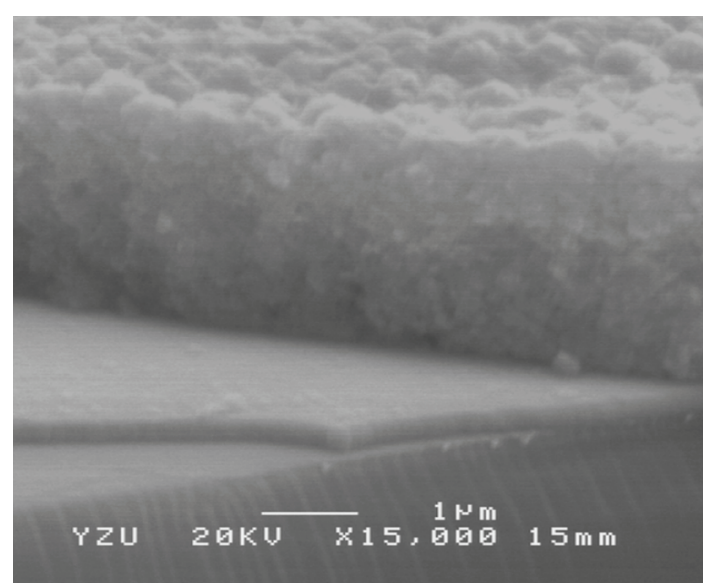

FIGURE 3: SEM photograph of cross section of CIGS precursor sample, revealing a sample thickness of $\sim 2 \mu \mathrm{m}$.

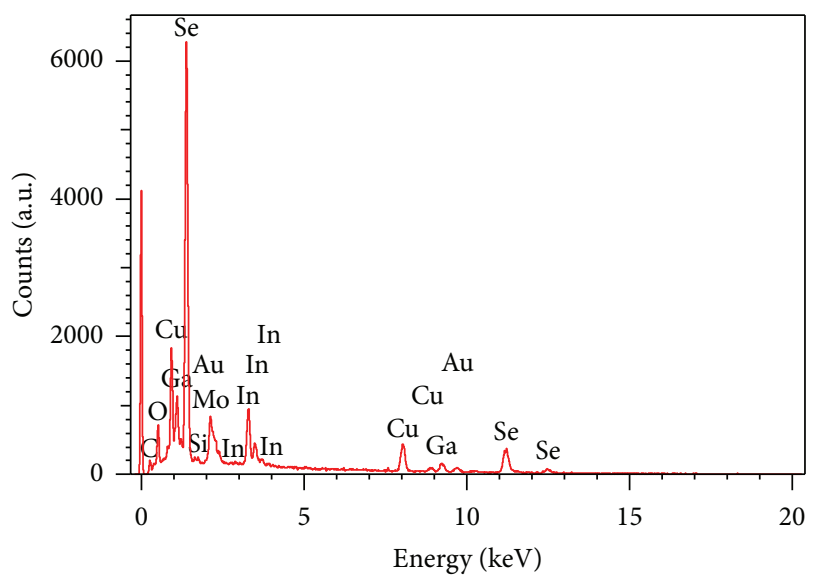

FIGURE 4: EDS photograph of CIGS sample sintered at $520^{\circ} \mathrm{C}$ for $30 \mathrm{~min}$.

related $\mathrm{Ga} /(\mathrm{In}+\mathrm{Ga}), \mathrm{Cu} /(\mathrm{In}+\mathrm{Ga})$, and $\mathrm{Se} /(\mathrm{Cu}+\mathrm{In}+\mathrm{Ga})$ ratios could be obtained.

Processes of sintering and selenization could significantly change the composition of the sample thin film: the ratio of $\mathrm{Ga} /(\mathrm{In}+\mathrm{Ga})$ decreased 0.119 ; the ratio of $\mathrm{Cu} /(\mathrm{In}+\mathrm{Ga})$ increased 0.068 , and the ratio of $\mathrm{Se} /(\mathrm{Cu}+\mathrm{In}+\mathrm{Ga})$ increased 0.568 , respectively. During sintering, selenium atoms would be to fill vacancy defects of the added $\mathrm{Cu}$, In, and $\mathrm{Ga}$ such that the related ratio of $\mathrm{Se} /(\mathrm{Cu}+\mathrm{In}+\mathrm{Ga})$ increased. Due to the minimum loss of indium atoms, the PVDF polymer on indium atoms could have a stronger binding. Sintered samples undergone selenization could form a Cu-poor CIGS film with a $\mathrm{Cu}: \mathrm{In}: \mathrm{Ga}:$ Se mole ratio of $0.617: 0.410: 0.510: 2.464$, that is, approximately $\mathrm{Cu}\left(\operatorname{In}_{1-x} \mathrm{Ga}_{x}\right)_{2} \mathrm{Se}_{3.5}$, which had been reported elsewhere [9]. Optimal heating for selenization could yield $\mathrm{Ga} /(\mathrm{In}+\mathrm{Ga})=0.554$ and $\mathrm{Cu} /(\mathrm{In}+\mathrm{Ga})=0.671$. At room temperature, the resistivity, mobility, and carrier concentration of the sintered CIGS sample determined by Hall measurements [21] were $5.6 E-3 \Omega \mathrm{cm}, 7.7 E+2 \mathrm{~cm}^{2} / \mathrm{Vs}$, 


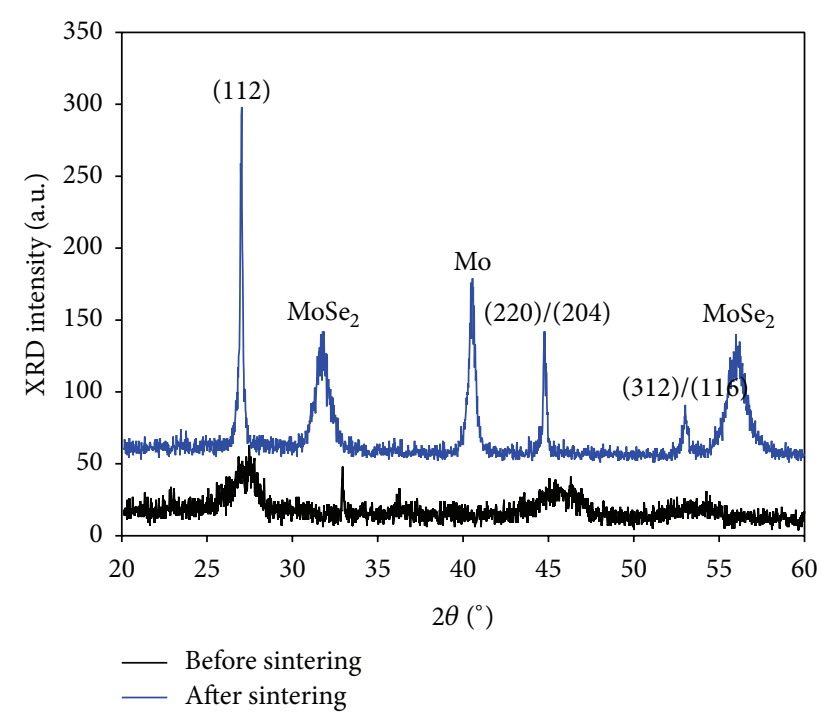

FIGURE 5: XRD patterns of CIGS samples before and after sintering.

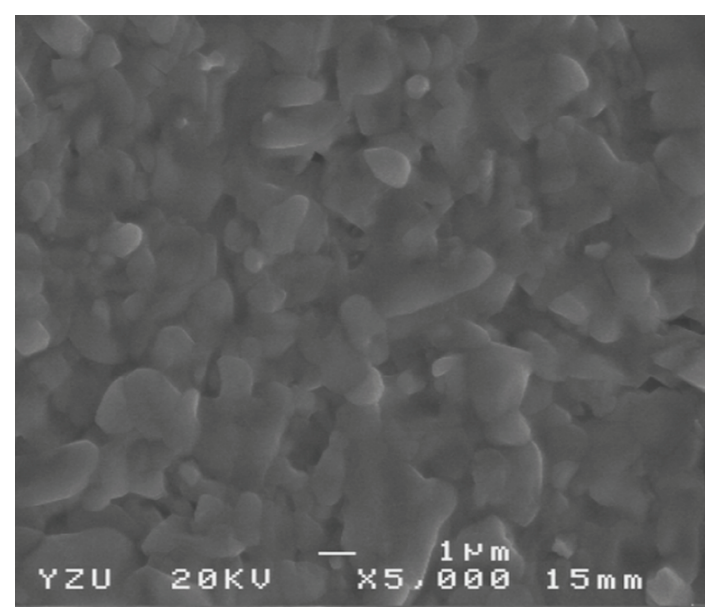

FIGURE 6: Surface SEM photographs of CIGS film layer.

and $1.45 E+18 \mathrm{~cm}^{-3}$, respectively. Furthermore, the sample prepared was p-type.

\subsection{Structural Characterization. Figure 5 presents XRD pat-} terns of samples before and after sintering. The grazing incidence angle was $1^{\circ}$ and diffraction angles were scanned from 20 to $60^{\circ}$. After sintering, it could be seen that the orientation of the sample was (112) after sintering, and the angle had changed from 27.47 to 27.03, as shown in Figure 5. As is well known, the full width at half maximum (FWHM) reflects the healing of point defects and grain growth [22]. For the sample sintered at $520^{\circ} \mathrm{C}$ for $30 \mathrm{~min}$, the angular FWHM of preferred orientation (112) would be reducing from $0.82^{\circ}$ to $0.19^{\circ}$. From the SEM photograph shown in Figure 6, it could also be observed that the surface of the CIGS layer had larger grains. Closely examining XRD patterns, it revealed that this sample was highly crystallized and the ratio of $\mathrm{Cu} /(\mathrm{In}+\mathrm{Ga})$ was 0.671 . During sintering, due to thermal activation, Se

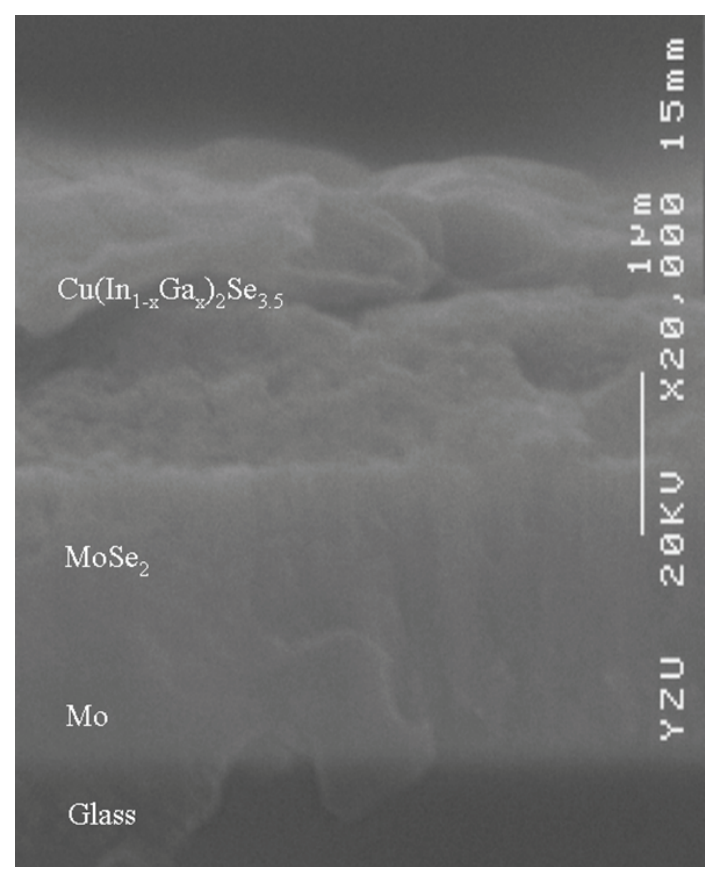

FIGURE 7: Cross-sectional SEM photographs of CIGS film layer.

atoms would quickly diffuse to occupy vacancies of each Se site of the CIGS layer, such that the ratio of $\mathrm{Se} /(\mathrm{Cu}+\mathrm{In}+$ $\mathrm{Ga}$ ) would be increasing. Because the interstitial diffusion on the surface of the CIGS layer was faster than that inside the layer, different structures could be formed respectively on the surface and inside the layer. From cross-sectional SEM image of the CIGS film shown in Figure 7, it can be seen that the thickness of the CIGS layer and the $\mathrm{MoSe}_{2}$ with Mo layer approximately is $1.5 \mu \mathrm{m}$ and $1.35 \mu \mathrm{m}$, respectively. From Figure 6, it can be seen that the surface morphology of the CIGS film is dense and granular. Furthermore, there is no columnar grain to be observed in cross-sectional image of the film, as shown in Figure 7. Before removing PVDF, the film on the surface is dense and crystallized, which is more easy to form the required chalcopyrite structure of $\mathrm{Cu}$-poor CIGS. From Figures 5 and 7, it can be observed that the crystal growth of $\mathrm{MoSe}_{2}$ comes from a combination of selenium and molybdenum. At high temperature for sintering, Mo atoms reacting with Se atoms could form $\mathrm{MoSe}_{2}$ [23]. It is noticed that the $\mathrm{MoSe}_{2}$ layer between the Mo and CIGS films is essential to form a good ohmic contact $[23,24]$.

3.3. Photovoltaic Applications. In order to test the photovoltaic effect, an ITO/ZnO/CdS/CIGS/Mo/glass solar cell with an active area of $0.35 \mathrm{~cm}^{2}$ was fabricated. The CIGS layer was deposited on the substrate of Mo/glass using the same method as that used for preparing the PVDF sample. The CdS layer was deposited on the CIGS layer by utilizing the chemical bath deposition (CBD) [25-28] and successively depositing the $\mathrm{ZnO}$ layer with the radio-frequency magnetron sputtering [29-31]. Then, a highly transparent ITO layer was deposited on the $\mathrm{ZnO}$ layer by using the direct current magnetron sputtering $[32,33]$ to complete the 


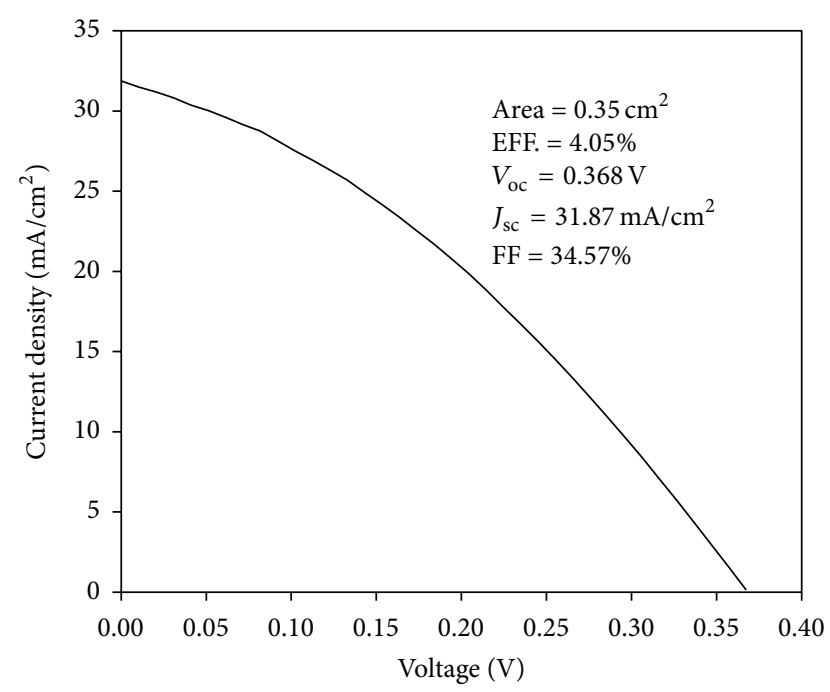

Figure 8: $I-V$ characteristics of CIGS thin-film solar cell under illumination.

whole solar cell. Under the condition of air mass 1.5 global illumination, the $I-V$ characteristics of a solar cell mounted on an absorber can be obtained, as shown in Figure 8. The measuring data of the cell shows that the open voltage $V_{\mathrm{oc}}$ is $0.368 \mathrm{~V}$, the current density $J_{\mathrm{sc}}$ is $31.87 \mathrm{~mA} / \mathrm{cm}^{2}$, the fill factor $\mathrm{FF}$ is $34.57 \%$, and the conversion efficiency is $4.05 \%$. The reason why the value of $V_{\text {oc }}$ of this solar cell sample becomes lower is that the high saturation current due to increased recombination in the CIGS solar cell, coupled with reduced shunt resistance and increased series resistance, resulted in a lower $V_{\mathrm{oc}}$, a lower $\mathrm{FF}$, and, consequently, lower conversion efficiency [34]. However, the saturation currents increased since they are derived from temperature-dependent quantities, such as the diffusion coefficient $D$, the carrier lifetime $\tau$, and the intrinsic carrier concentration $n_{\mathrm{i}}$ [35]. This resulted in increased recombination currents which reduced $V_{\mathrm{oc}}, P_{\max }$, and FF. Also, the extracted values reflect the adverse effect of temperature on parasitic resistance. For this solar cell sample, the high saturation current due to increased recombination in the CIGS solar cell, coupled with reduced shunt resistance and increased series resistance, resulted in a lower $V_{\text {oc }}$, a lower $\mathrm{FF}$, and, consequently, lower conversion efficiency.

\section{Conclusions}

Cu-poor CIGS nanoparticles with a chalcopyrite structure for solar cells were successfully synthesized by using a relatively simple and convenient elemental solvothermal route. In this approach, Cu-poor CIGS nanoparticles, a solvent, and an organic polymer are mixed together to prepare the nanoparticle ink. Analytical results reveal that the Cu-poor CIGS absorption layer prepared by sintering from nanoparticleink polymer had a chalcopyrite structure and a favorable composition ratio. The mole ratio of $\mathrm{Cu}: \mathrm{In}: \mathrm{Ga}: \mathrm{Se}$ of the sample was $0.617: 0.410: 0.510: 2.464$ and related ratios of $\mathrm{Ga} /(\mathrm{In}+\mathrm{Ga})$ and $\mathrm{Cu} /(\mathrm{In}+\mathrm{Ga})$ were 0.554 and 0.671 , respectively. In addition, the resistivity, mobility, and carrier concentration of the sample were $5.6 E-3 \Omega \mathrm{cm}, 7.7 E+$ $2 \mathrm{~cm}^{2} / \mathrm{Vs}$, and $1.45 E+18 \mathrm{~cm}^{-3}$, respectively. Under the standard test conditions of air mass 1.5 global illumination, it can be seen that the conversion efficiency of the solar cell fabricated is $4.05 \%$.

\section{Conflict of Interests}

The authors of this paper declare that there is no conflict of interests regarding the publication of this paper.

\section{Acknowledgment}

The authors would like to thank the National Science Council of the Republic of China, Taiwan, for financially supporting this research under Contracts nos. NSC 99-2221-E-155-051 and NSC 100-2221-E-155-045.

\section{References}

[1] T. M. Razykov, C. S. Ferekides, D. Morel, E. Stefanakos, H. S. Ullal, and H. M. Upadhyaya, "Solar photovoltaic electricity: current status and future prospects," Solar Energy, vol. 85, no. 8, pp. 1580-1608, 2011.

[2] P. Jackson, D. Hariskos, E. Lotter et al., "New world record efficiency for $\mathrm{Cu}(\mathrm{In}, \mathrm{Ga}) \mathrm{Se}_{2}$ thin-film solar cells beyond $20 \%$," Progress in Photovoltaics: Research and Applications, vol. 19, no. 7, pp. 894-897, 2011.

[3] M. A. Green, K. Emery, Y. Hishikawa, and W. Warta, "Solar cell efficiency tables (version 37)," Progress in Photovoltaics: Research and Applications, vol. 19, no. 1, pp. 84-92, 2011.

[4] R. Scheer, A. Neisser, K. Sakurai, P. Fons, and S. Niki, " $\mathrm{Cu}\left(\mathrm{In}_{1-x} \mathrm{Ga}_{x}\right) \mathrm{Se}_{2}$ growth studies by in situ spectroscopic light scattering," Applied Physics Letters, vol. 82, no. 13, pp. 2091-2093, 2003.

[5] A. Chirilǎ, S. Buecheler, F. Pianezzi et al., "Highly efficient $\mathrm{Cu}(\mathrm{In}, \mathrm{Ga}) \mathrm{Se}_{2}$ solar cells grown on flexible polymer films," Nature Materials, vol. 10, no. 11, pp. 857-861, 2011.

[6] J. C. Mikkelsen Jr., "Ternary phase relations of the chalcopyrite compound $\mathrm{CuGaSe}_{2}$," Journal of Electronic Materials, vol. 10, no. 3, pp. 541-558, 1981.

[7] D. Schmid, M. Ruckh, F. Grunwald, and H. W. Schock, "Chalcopyrite/defect chalcopyrite heterojunctions on the basis of CuInSe ${ }_{2}$," Journal of Applied Physics, vol. 73, no. 6, pp. 29022909, 1993.

[8] J. Kessler, D. Schmid, R. Schäffler, H. W. Schock, and S. Menezes, "Electro-optical and photoelectrochemical studies of $\mathrm{CuIn}_{3} \mathrm{Se}_{5}$ chalcopyrite films," in Proceedings of the 23rd IEEE Photovoltaic Specialists Conference, pp. 549-556, IEEE, Louisville, Ky, USA, May 1993.

[9] T. Tanaka, N. Tanahashi, T. Yamaguchi, and A. Yoshida, "Characterization of $\mathrm{Cu}\left(\mathrm{In}_{x} \mathrm{Ga}_{1-x}\right)_{2} \mathrm{Se}_{3.5}$ thin films prepared by $\mathrm{rf}$ sputtering," Solar Energy Materials and Solar Cells, vol. 50, no. 1-4, pp. 13-18, 1998.

[10] H. Z. Xiao, L.-C. Yang, and A. Rockett, "Structural, optical, and electrical properties of epitaxial chalcopyrite $\mathrm{CuIn}_{3} \mathrm{Se}_{5}$ films," Journal of Applied Physics, vol. 76, no. 3, pp. 1503-1510, 1994.

[11] S. Nishiwaki, T. Satoh, S. Hayashi et al., "Preparation of $\mathrm{Cu}(\mathrm{In}, \mathrm{Ga}) \mathrm{Se}_{2}$ thin films from $\mathrm{Cu}-\mathrm{Se} / \mathrm{In}-\mathrm{Ga}$-Se precursors for high-efficiency solar cells," Journal of Materials Research, vol. 14, no. 12 , p. $4514,1999$. 
[12] E. Lee, J. W. Cho, J. Kim, J. Yun, J. H. Kim, and B. K. Min, "Synthesis of CIGS powders: transition from binary to quaternary crystalline structure," Journal of Alloys and Compounds, vol. 506, no. 2, pp. 969-972, 2010.

[13] T. Wada, Y. Matsuo, S. Nomura et al., "Fabrication of $\mathrm{Cu}(\mathrm{In}, \mathrm{Ga}) \mathrm{Se}_{2}$ thin films by a combination of mechanochemical and screen-printing/sintering processes," Physica Status Solidi A, vol. 203, no. 11, pp. 2593-2597, 2006.

[14] C. P. Liu and C. L. Chuang, "Fabrication of copper-indiumgallium-diselenide absorber layer by quaternary-alloy nanoparticles for solar cell applications," Solar Energy, vol. 86, no. 9, pp. 2795-2801, 2012.

[15] S. Ahn, C. Kim, J. Yun, J. Lee, and K. Yoon, "Effects of heat treatments on the properties of $\mathrm{Cu}(\mathrm{In}, \mathrm{Ga}) \mathrm{Se}_{2}$ nanoparticles," Solar Energy Materials and Solar Cells, vol. 91, no. 19, pp. 18361841, 2007.

[16] S. Yoon, T. Yoon, K.-S. Lee, S. Yoon, J. M. Ha, and S. Choe, "Nanoparticle-based approach for the formation of CIS solar cells," Solar Energy Materials and Solar Cells, vol. 93, no. 6-7, pp. 783-788, 2009.

[17] E. Lee, S. J. Park, J. W. Cho, J. Gwak, M.-K. Oh, and B. K. Min, "Nearly carbon-free printable CIGS thin films for solar cell applications," Solar Energy Materials and Solar Cells, vol. 95, no. 10, pp. 2928-2932, 2011.

[18] G. Gordillo, M. Grizález, and L. C. Hernandez, "Structural and electrical properties of DC sputtered molybdenum films," Solar Energy Materials and Solar Cells, vol. 51, no. 3-4, pp. 327-337, 1998.

[19] Y. Jiang, Y. Wu, X. Mo, W. Yu, Y. Xie, and Y. Qian, "Elemental solvothermal reaction to produce ternary semiconductor $\mathrm{CuInE}_{2}(\mathrm{E}=\mathrm{S}, \mathrm{Se})$ nanorods," Inorganic Chemistry, vol. 39, no. 14, pp. 2964-2965, 2000.

[20] B. Li, Y. Xie, J. Huang, and Y. Qian, "Synthesis by a solvothermal route and characterization of $\mathrm{CuInSe}_{2}$ nanowhiskers and nanoparticles," Advanced Materials, vol. 11, no. 17, pp. 1456-1459, 1999.

[21] L. J. van der Pauw, "A method of measuring specific resistivity and Hall effect of discs of arbitrary shape," Philips Research Reports, vol. 13, p. 1, 1958.

[22] T. Schlenker, M. L. Valero, H. W. Schock, and J. H. Werner, "Grain growth studies of thin $\mathrm{Cu}(\mathrm{In}, \mathrm{Ga}) \mathrm{Se}_{2}$ films," Journal of Crystal Growth, vol. 264, no. 1-3, pp. 178-183, 2004.

[23] D. Abou-Ras, G. Kostorz, D. Bremaud et al., "Formation and characterisation of $\mathrm{MoSe}_{2}$ for $\mathrm{Cu}(\mathrm{In}, \mathrm{Ga}) \mathrm{Se}_{2}$ based solar cells," Thin Solid Films, vol. 480-481, pp. 433-438, 2005.

[24] T. Wada, N. Kohara, S. Nishiwaki, and T. Negami, "Characterization of the $\mathrm{Cu}(\mathrm{In}, \mathrm{Ga}) \mathrm{Se}_{2} / \mathrm{Mo}$ interface in CIGS solar cells," Thin Solid Films, vol. 387, no. 1-2, pp. 118-122, 2001.

[25] R. N. Bhattacharya and K. Ramanathan, "Cu(In,Ga)Se ${ }_{2}$ thin film solar cells with buffer layer alternative to CdS," Solar Energy, vol. 77, no. 6, pp. 679-683, 2004.

[26] T. M. Razykov, S. Z. Karazhanov, A. Y. Leiderman, N. F. Khusainova, and K. Kouchkarov, "Effect of the grain boundaries on the conductivity and current transport in II-VI films," Solar Energy Materials and Solar Cells, vol. 90, no. 15, pp. 2255-2262, 2006.

[27] M. D. Archbold, D. P. Halliday, K. Durose et al., "Development of low temperature approaches to device quality CdS: a modified geometry for solution growth of thin films and their characterisation," Thin Solid Films, vol. 515, no. 5, pp. 2954-2957, 2007.
[28] C. P. Liu and C. L. Chuang, "Annealing-induced changes in composition and optoelectronic properties of cadmium sulfide films used in copper-indium-gallium-diselenide solar cells," Solar Energy, vol. 86, no. 5, pp. 1605-1610, 2012.

[29] S. Ishizuka, K. Sakurai, A. Yamada et al., "Fabrication of widegap $\mathrm{Cu}\left(\mathrm{In}_{1-x} \mathrm{Ga}_{x}\right) \mathrm{Se}_{2}$ thin film solar cells: a study on the correlation of cell performance with highly resistive i- $\mathrm{ZnO}$ layer thickness," Solar Energy Materials and Solar Cells, vol. 87, no. 14, pp. 541-548, 2005.

[30] D. J. Kang, J. S. Kim, S. W. Jeong, Y. Roh, S. H. Jeong, and J. H. Boo, "Structural and electrical characteristics of R.F. magnetron sputtered ZnO films," Thin Solid Films, vol. 475, no. 1-2, pp. 160$165,2005$.

[31] K. A. Salman, K. Omar, and Z. Hassan, "Effective conversion efficiency enhancement of solar cell using $\mathrm{ZnO} / \mathrm{PS}$ antireflection coating layers," Solar Energy, vol. 86, no. 1, pp. 541-547, 2012.

[32] U. Betz, M. K. Olsson, J. Marthy, and M. F. Escolá, “On the synthesis of ultra smooth ITO thin films by conventional direct current magnetron sputtering," Thin Solid Films, vol. 516, no. 7, pp. 1334-1340, 2008.

[33] H. Liu and C. Lei, "Low-temperature deposited Titaniumdoped zinc oxide thin films on the flexible PET substrate by DC magnetron sputtering," Vacuum, vol. 86, no. 4, pp. 483-486, 2011.

[34] E. Q. B. Macabebe, C. J. Sheppard, and E. E. van Dyk, "Parameter extraction from I-V characteristics of PV devices," Solar Energy, vol. 85, no. 1, pp. 12-18, 2011.

[35] S. M. Sze, Physics of Semiconductor Devices, John Wiley \& Sons, New York, NY, USA, 2nd edition, 1981. 

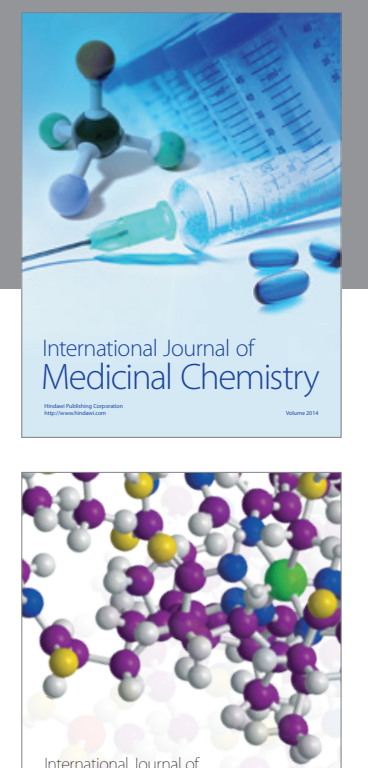

\section{Carbohydrate} Chemistry

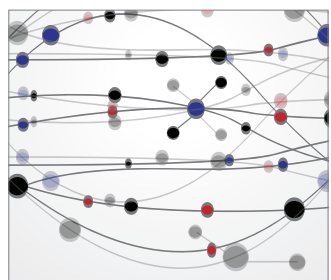

The Scientific World Journal
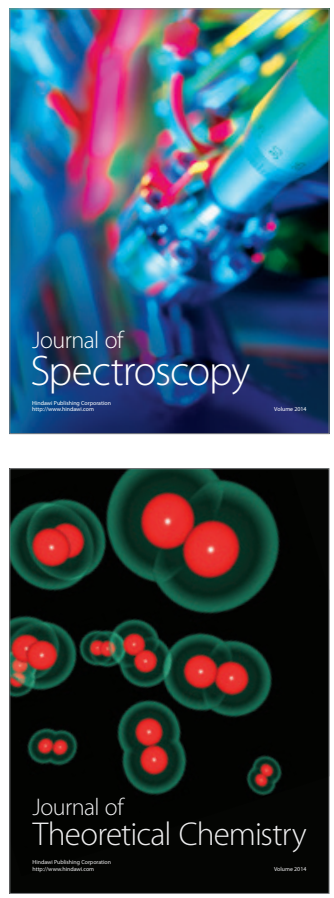
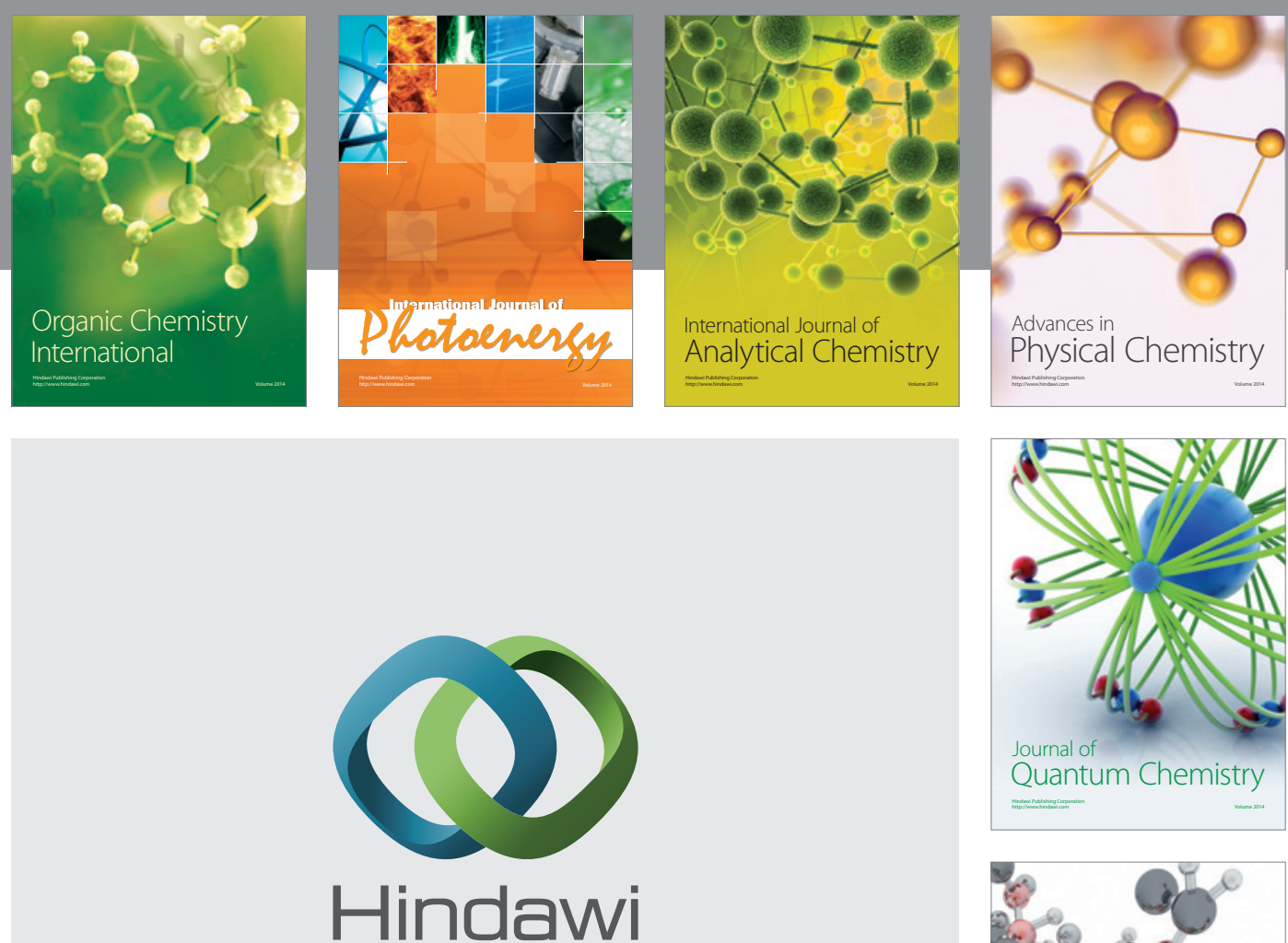

Submit your manuscripts at

http://www.hindawi.com

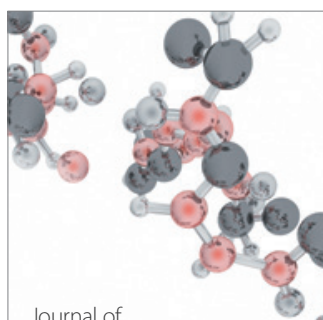

Analytical Methods

in Chemistry

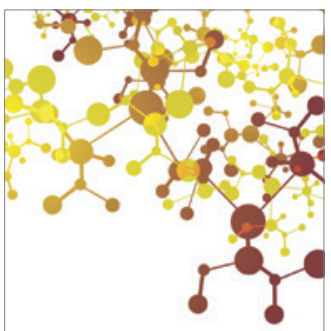

Journal of

Applied Chemistry

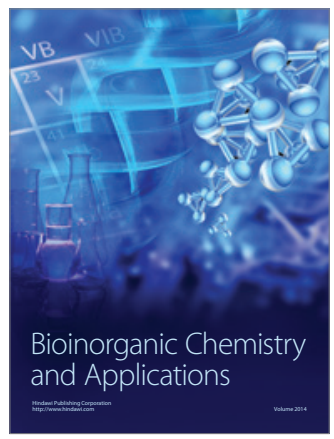

Inorganic Chemistry
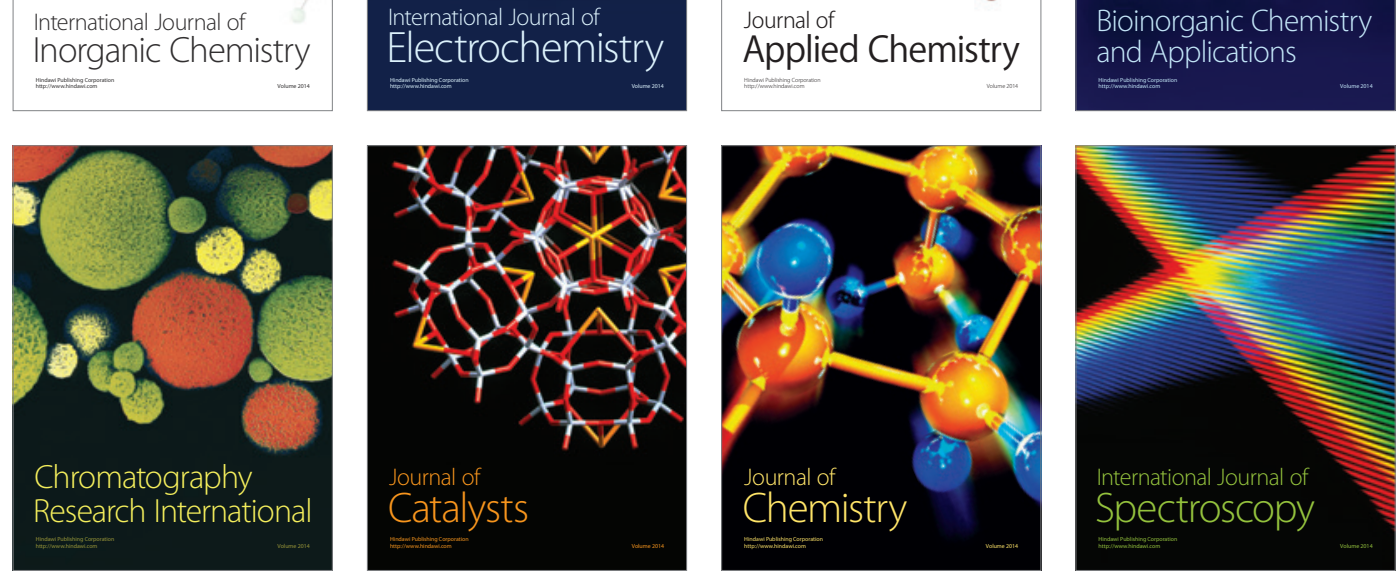